\title{
Swart Teologie en Suid-Afrika se kairós
}

\section{JJ Kritzinger}

\begin{abstract}
Black Theology and South Africa's kairós

South Africa's Black Theology must be seen as a local contextual theology, but with roots in al least the American Black Theology, Latin American Liberation Theology as well as African Theology. After dealing with these roots, and the different trends in Black Theology, this theology is related to the Kairos Document of September 1985. The conclusion is that this Document can be regarded as the latest and clearest expression of Black Theology. As such it is a formidable challenge to the church and conventional theology.
\end{abstract}

\section{INLEIDING}

Oor die Swart Teologie word daar vanaf 1970 hier te lande baie geskryf en gepraat. Dit was ongeveer die jaar dat die term vir die eerste keer in sirkulasie gekom het, en wel in Amerika waar veral James Cone, professor aan Union Theological Seminary (New York), die nuwe teologie gepropageer het. Sedertdien het talle woordvoerders en kritici gesorg dat dit ' $n$ wydvertakte en breed uitgewerkte beweging geword het. Sedert die tydskrif Missionalia in 1977 'n afsonderlike kategorie vir artikels oor Swart Teologie ingestel het, is nie minder nie as 98 sulke wetenskaplike artikels deur die tydskrif opgesom. En dan is die boeke nie eers ingereken nie!

Enige poging om Swart Teologie in enkele trekke te teken, is dus tot veralgemenings en dikwels onaanvaarbare vereenvoudigings gedoem. Nogtans probeer ons weer ' $n$ keer hierdie verskynsel bespreek. Ons interesse is hoofsaaklik om die agtergrond te begryp sodat sinvol met die Swart Teologie in gesprek getree kan word. Die vraag in watter mate die Kairos Dokument van September 1985 (met 'n eerste hersiening in Augustus 1986) voorlopig die kroon span op die Suid-Afrikaanse Swart Teologie sal taamlik rigtinggewend wees.

Is dit so dat daar in die afgelope jaar of wat baie min sprake was van die Swart Teologie en dat selfs voorstanders die begrip nie meer gebruik nie? Het die 'Profetiese Teologie' van die Kairos Dokument dalk die Swart Teologie vervang? Of is dit 'n bloot akademiese en hipote- 
tiese vraag omdat die Swart Teologie in werklikheid net 'n soort teologie, ' $n$ benadering tot die teologie, wil wees?

Om hierdie soort vrae te ondersoek, sal ons eers die Swart Teologie in sy breër verband met die Bevrydingsteologie nagaan; dan sal sy wortels in Afrika aangedui word. Die breë strominge binne die Swart Teologie en (ander se) pogings tot klassifikasie sal dan lei tot die Kairos Dokument.

\section{SWART TEOLOGIE EN BEVRYDINGSTEOLOGIE}

\subsection{Swart Teologie}

Die Swart Teologie het sy ontstaan in die VSA gehad. Met groot begrip skets prof CWH Boshoff die swart ervaring in die VSA in sy 1980-boek.

Sedert die eerste Negerslawe in 1619 na Noord-Amerika geneem is, moes hulle 'n eeuelange geskiedenis van uitbuiting en veragting beleef. Alle spore van hulle oorspronklike kultuur is hulle ontneem en opstande teen die onmenslike stelsel en onaanvaarbare omstandighede is bloedig onderdruk. Wetgewing het 'n sterk beheer verseker. Slegs met groot moeite kon Negers hulle vryheid verwerf.

Wat moeilik verwerk kon word, was die algemene ondervinding van diskriminasie, selfs teen die vrye Swartes (Free Blacks). Vir meer as 'n eeu ná die algehele vrystelling van slawe sou daar nog talle beperkinge vir die Swartes wees. Paswette waardeur bewegingsvryheid aan bande gelê is, was algemeen. Werksafbakening het hulle grootliks tot armoede veroordeel. Die (gesegregeerde) onderwys het hulle groot agterstande besorg, in sekere state kon hulle selfs nie eiendom besit nie. Op die wreedste maniere het Blankes hulle rassehaat op die Swartes uitgegiet.

In 'n sekere sin was die 1954-besluit van die Hooggeregshof teen gesegregeerde skole ' $n$ waterskeiding. Die Blankes het hulle geledere in weerstand gesluit, maar die Swartes kon nie langer ondergehou word nie. Onder leiding van veral Martin Luther King is bewys dat daar 'n groot mag in solidariteit is: die Wet op Burgerregte is in 1964 afgedwing. Swart Mag het opgestaan. Die stryd, nie alleen om ware gelykberegtiging nie, maar om 'n nuwe persoonlike waardigheid was egter nog nie verby nie.

Die Swart Ervaring van eeue en die ontwaking van Swart Mag het sy gevolge en reaksies op alle lewensterreine gehad. Een van die belangrike uitings daarvan was die nuwe uitsig op die teologie. In die inleiding tot die eerste versameling artikels, wat deur 'n verskeidenheid 
outeurs geskryf is en getitel is, Quest for a Black Theology, skryf J Deotis Roberts (1971: ix):

Just as the 'invisible church' of the black man preceded the visible organization even so an indigenous black theology has appeared here and there in sermon, spiritual and black folk expression ... It has not appeared before in writing.

In hierdie teologie speel die Swartes se ervaring, geskiedenis en kultuur dus bewustelik 'n groot rol.

Dit is voor-die-hand-liggend dat die gesofistikeerde Swartes van Suid-Afrika groot aanvoeling vir hierdie teologie sou hê. Is dit nie so dat hulle ervaring 'n hoë ooreenstemming met dié van die VSA-Negers toon nie? (Die profetiese boek van prof Ben J Marais, Die Kleurkrisis en die Weste. Johannesburg: Goeie Hoop Uitgewers, 1952, het reeds aangedui hoedanig die ooreenkomste is.) Dit was dus veral die geskrifte van James Cone wat op georganiseerde wyse na Suid-Afrika oorgebring is deur middel van seminare in die loop van 1971.

\subsection{Bevrydingsteologie}

Swart Teologie kan egter nie in isolasie gesien word van die LatynsAmerikaanse Bevrydingsteologie wat ongeveer dieselfde tyd in beweging begin kom het nie, dié 'Genetief-teologie' wat miskien die langdurigste en wydste verbreiding geniet het.

Waar die Swart Teologie sy ontstaan gehad het in die ervaring van Swartmense in 'n blanke-oorheerste-samelewing waar kleur en rassisme die aktuele faktore was, ontwikkel die Bevrydingsteologie in 'n konteks wat as 'n klasse-spanning beskryf kan word: 'n arm bevolking wat deur 'n ryk en magtige heersersklas ondergehou word. Hierdie kloof tussen ' $n$ rykerwordende elite en 'n steeds afwaarts-ontwikkelende meerderheid verteenwoordig so 'n algemene wêreldprobleem (veral in die sg Derde Wêreld) dat dit verstaanbaar is dat ' $n$ teologie wat uit so 'n situasie gebore is, vir vele mense aantreklik sal wees. Inderdaad vorm die VSA en Suid-Afrikaanse situasie spesiale gevalle van die breëre probleem soos in Latyns-Amerika geskets.

Bevrydingsteologie was dus die toonbeeld - en in baie opsigte die voorloper - van die kontekstuele teologieë. Twee verwante aspekte lê gevolglik ten grondslag van sy opkoms: eerstens 'n sekere wyse om na die polities-ekonomiese werklikheid te kyk, en tweedens 'n nuwe manier om teologie te beoefen (doing theology). 
Neely (1978: 345) wys op 'n aantal sekulêre invloede wat die ontwikkeling van die Bevrydingsteologie vooruitgeloop het. Ons noem die drie gedagterigtings wat Neely meen 'n besondere invloed gehad het.

Die eerste is die dialektiese materialisme en antroposentrisme van die Marxisme. Hegel het reeds die klem begin lê op die mens as die maker van geskiedenis en gesê dat geskiedenis alleen maar die proses van die bevryding van die mens is. Marx se bekende spreuk was dat die filosowe slegs die wêreld verklaar het, maar dat die belangrikste ding is om die wêreld te verander. Marx se kritiek op godsdiens was dat dit die heersende klasse van 'n ideologie bedien het wat gemanipuleer kon word om die sosiale strukture (die status quo) onveranderd te behou. Bevrydingsteologie sou hierdie stelling rustig kon toepas op die tradisionele kerklike strukture wat in beheer van die elite was. Daarby het die Marxisme ook gekom met die aantreklike analise van sosiopolitieke probleme as synde die konflik tussen die heersende en onderdrukte klasse. Die ekonomiese beleid van die kapitalisme dien verder om die ongelykhede te bestendig. By al hierdie en ander gedagtes het die teoloë van die bevryding aangeknoop, met 'n mindere of ' $n$ meerdere mate van instemming.

Die tweede intellektuele stroom was die stroom van kritiek teen die ontwikkelingsdenke. Die eerste ontwikkelingsdekade is deur die VV afgeskop met U Thant se formule: ontwikkeling = ekonomiese groei plus sosiale verandering. Die Wêreldraad van Kerke, die Vatikaan en die Noord-Atlantiese lande het met groot ywer die saak van ontwikkeling begin stoot. Spoedig het kritiese stemme egter begin opgaan: Wanneer gaan die beloofde voordele begin waar word? Teen die middel-sestigerjare het die feite aan die lig begin kom: in werklikheid word die afhanklikheid van die 'Eerste Wêreld' net al erger, die multinasionale maatskappye word die nuwe imperialiste. Frank (kyk Neely 1978: 349) het die cliché, 'die ontwikkeling van onderontwikkeling', gevorm. Al meer is aanvaar dat die armoede en 'onderontwikkeling' net die donker skaduwee is van die 'ontwikkeling' van die nywerheidslande in die Noorde. Die skynbare vriende met hulle aanbiedinge vir ontwikkeling blyk die eintlike vyande van onafhanklikheid en selfstandigheid te wees. Bevryding word al meer die mikpunt en die ekonomiese ideologieë van ontwikkeling (kapitalisme, vrye onderneming, ens) en hulle teologiese stutte word die aartsvyande.

Derdens het 'n groep, waarvan Paulo Freire en Ivan Illich prominent was, die gedagte van psigologiese bevryding ontwikkel. Onderdruk- 
king van mense laat diep geestelike letsels wat nie maklik opgelos kan word nie.

Bevryding is nie iets wat aan jou gedoen kan word nie, dit moet uit die persoon self kom. Ware bevryding moet dus voorafgegaan en vergesel word van ' $\mathrm{n}$ proses van bewuswording (consciousness raising of conscientization). Die onderdruktes moes gehelp word vanaf ' $n$ toestand van 'n naïewe aanvaarding van alles wat oor hulle kom (fatalisme) tot 'n kritiese ingesteldheid wat bevraag, uitdaag en om verandering soek. Bevryding is ten diepste 'n opvoedkundige proses - maar nie die resultaat van die oorgelewerde skool-stelsel nie. Tradisionele onderwys het juis die ongelyke status quo versterk en moet mee weggedoen word. Daar moet ook krities gekyk word na die gedagtes rondom geweld. Dit het tyd geword om die ekonomiese verslawing te sien vir wat dit werklik is, naamlik institusionele geweld. Teengeweld is nie alleen in die lig daarvan verstaanbaar nie, maar heel dikwels positief terapeuties omdat dit innerlike bevryding kan bevorder.

Hierdie soort gedagtes het in Latyns-Amerika op vrugbare aarde geval en het op sekulêre gebied ook duidelike gevolg gehad. Die Kubaanse revolusie van 1959 en die gebeure in Chili, Guatamala, Nicaragua en ander plekke het die lewenskragtigheid van hierdie soort gedagtes gedemonstreer. Die teoloë wat nie vrede gehad het met die status quo nie, is grootliks deur hierdie gebeure en gedagtes beïnvloed.

Maar ook in die Europese en Noord-Amerikaanse teologie was bewegings aan die gang wat die teologiese wêreld verander het. Die teologie van die hoop van Jürgen Moltmann, gekoppel met die politieke teologie van Johann B Metz (om maar net dié twee te noem) het Latyns-Amerikaanse teoloë bevrug en aan die dink gesit. Guttiérrez, Assmann, Segundo, Alves en andere se geskrifte toon baie duidelike tekens dat hulle deur teoloë soos Moltmann, Metz en Bonhoeffer beïnvloed is.

Saam met wyle prof J Alex van Wyk (1977: 86v) kan ons die (Protestantse) Bevrydingsteologie soos volg breedweg tipeer:

Eerstens wil dit 'n nuwe tipe teologie wees wat meer belangstel in die praxis as in die akademiese diskussie. Hierdie teologie word daarom gedoen en vloei voort uit die betrokkenheid by wat beskou word as God se bevrydende aksies in die samelewing. Die honger tot bevryding kom van God - en die teologie moet daarby aanknoop. Die tekens van die tye moet raakgesien word. Teologie is in werklikheid die nadenke, vanuit 'n gelowige perspektief, op die sosio-politieke gebeure. Teoloë moet betrokke wees by die armes en gedronge wees 
deur die stryd om bevryding. Die teologie moet dus induktief wees (vanuit die situasie na die beginsels beweeg) en nie deduktief soos die tradisionele teologie nie.

In die tweede plek is die benadering tot die kerk hoofsaaklik sosiopolities en ideologies. Die merkteken van die ware kerk is praxeologies: Is die kerk aan die kant van die armes en betrokke by God se dade van bevryding? Nòg die kerke wat hulleself onttrek aan die politiek, nòg dié wat aan aanpassing glo, maar alleen dié wat werk vir radikale transformasie (revolusie), is op die regte spoor. Ook die kerk se pastoraat moet hierop gerig word: Kerklede moet geskool word om God se kairós te herken. Die volk van God moet toegerus word vir aksie en betrokkenheid in God se bevrydingswerk. 'n Nuwe kerk word verlang: die kerk van die armes, die kerk van môre (vgl prof Gustav Bam se kritiek hierop in Die Ligdraer, 1985).

Wat sending betref, word die inkarnasie-model voorgestel. Die Bevrydingsteologie is basies missionêre teologie, want kerk is sending. Missiologie is die kritiese nadenke oor die kerk se missionêre praktyk. Dit vra dus betrokkenheid in die lewe van die gewone mense wat stry om 'n meer menslike wêreld. Betrokkenheid sal ook konflik meebring, maar daarvoor kan nie teruggedeins word nie. Trouens, alleen deur so 'n solidariteit kan geloofwaardigheid en die reg om te spreek, verdien word.

Die vierde kenmerk van die Bevrydingsteologie is sy bedding in die sosio-politieke realiteite van Latyns-Amerika. 'n Analise van die situasie lê bewustelik ten basis van die teologie. Soos reeds gesien, word die Marxistiese analise van die sosiale ontwikkeling as 'n klassestryd begunstig en aanvaar as die mees wetenskaplike verklaring. Die konsep van 'die armes' word grondliggend, en wel in die Marxisties-Leninistiese sin van die woord, rtaamlik dat armoede die gevolg is van rykdom. Wat belangrik is, is om aktief en militant deel te wees van die regverdige stryd. Daar sal wel praktiese probleme na vore kom, maar dit moet beoordeel word in die lig van die onderskeiding tussen die 'laaste' en 'voorlaaste' dinge.

Laastens moet gewys word op die feit dat die klem op die mens val en in die besonder op die gewone mens, dié wat beskryf word as 'die armes'. Die mens se totale situasie is belangrik, nie net sy geestelike lewe nie. Sy armoede is nie maar net 'n onverskillige saak nie, maar is die gevolg van uitbuiting en onderdrukking: daar is armoede omdat daar rykdom is. Individualisme word verwerp, solidariteit is die kernbegrip. Soos in die Marxisme word gepraat van die 'massas', die krag lê 
in die volk (people). Nie alleen die kruis van Christus en sy lyding, maar veral sy opstanding en oorwinning, word direk aangegryp.

Kritiek sou teen allerlei aspekte van die Bevrydingsteologie ingebring kon word. Van Wyk (1977: 89vv) wys op die gevaar van 'n ideologiese analise wat ten basis van 'n teologie kan lê. Hy wys ook op die vraagtekens wat agter die praxeologiese norm geplaas sou kon word en die feit dat betrokkenheid daardeur gemotiveer mag word. Die gevaar dreig dat ook die sending kan opgaan in ' $n$ blote handperd van ' $n$ ideologiese stryd. Die inkarnasiemodel hou ook 'n oordeel in. Word daar genoegsaam hieraan aandag gegee?

Clodovis Boff (1985: 168vv) wys egter daarop dat daar heelwat mites omtrent die Bevrydingsteologie is wat reggestel moet word. Hy ontken eerstens dat die Bevrydingsteologie van die Marxisme en 'liberale teologie' van Bultmann afstam. Nee, die eintlike vaders is enersyds die hiërargiese kerk en andersyds die onderdrukte Christene van LatynsAmerika. ' $n$ Tweede mite is dié van die geestelike verskraling. Nooit tevore, so sê hy, is daar deur die volk soveel Bybel gelees en gebid nie! Ook in hierdie opsig is die praktyk van die Bevrydingsteologie beter as sy teorie!

Derdens neem hy eksepsie teen die bewerings dat die Bevrydingsteologie maar eintlik Marxisme in 'n ander gedaante is. Nee, die Marxisme is nòg die motor nòg die basis, maar die Christelike geloof is. Eintlik word maar van Marxistiese analises gebruik gemaak - en nie altyd versigtig genoeg nie, sê hy - maar dit is al.

As die Bevrydingsteologie, in die laaste instansie, afgemaak word as 'onwetenskaplik' en 'pragmaties', wil hy toegee dat dit ' $n$ jong teologie is. Maar die wedervraag aan die ou, sogenaamde wetenskaplike teologie van die Eerste Wêreld is dit: Hoeveel daarvan lei tot evangelies geïnspireerde kerklike lewe?

Uiteraard kan ons nie hier 'n gebalanseerde en deeglike analise en kritiek bied nie, maar ons moet op vele van Boff se punte toegee. Hy noem tien winspunte van die Bevrydingsteologie (Boff 1985: 174-176):

- Hulle het daaraan herinner dat daar armes in die wêreld is wat om hulle bevryding stry.

- Hulle het indringend aangedui dat die evangeliegeloof bevrydend is.

- Hulle het die waarheid dat die gewone mense die kern van die kerk uitmaak, sterk na vore gebring.

- Hulle het herinner dat die teologie die 'tweede daad' is wat moet voortvloei uit die 'eerste daad', naamlik die gelowige lewe. 
- Hulle het die arena van teologie vanaf die klaskamer na die gemeente verskuif.

- Hulle het teoloë gedwing om by die konkrete praktyk uit te kom.

- Hulle het die teologie en die volk weer nader aan mekaar gebring.

- Hulle het die teologie weer openbare saak gemaak en iets wat in die openbaar gewig dra.

- Hulle het hulle toegespits op die positiewe benutting van die sosiale wetenskappe.

- Hulle het die gesprek oor die Marxisme op 'n nuwe vlak geplaas, naamlik in diens van die bevryding van die armes.

Al sou hierdie apologie nie in alle opsigte oortuigend wees nie, kan ons reeds aanvoel dat die volgende veroordeling ietwat oordrewe is (in The Reformation Review 24/4, 1979: 214):

Therefore, we declare that 'liberation theology', as defended and taught today under Marxist analysis, although clothed in religious terminology is satanic in its origin; political in its interests; deceptive in its promises; inhuman and oppressive in its social ethic; tyrannical in its nature; destructive ... etc, etc. (Verklaring van die International Council of Christian Churches - ICCC Junie 1979.)

Myns insiens sal die teologie 'n paar beklemtonings van die Bevrydingsteologie nie meer kan ignoreer nie. Ek noem drie:

- Dat die 'armes' besondere aandag van die kerk moet ontvang, is die deurlopende beklemtoning van die Woord van God in Ou en Nuwe Testament.

- Dat die kwaad nie net persoonlik en individueel gesien moet word nie, maar dat dit ook skuilgaan in strukture, samelewingsordes en ideologieë en dat die kerk daarom ook 'n strukturele taak het.

- Dat ook die teologie, en die interpretasie van die Bybel, nie objektief en absoluut kan geskied nie, maar dat die teoloog se eie posisie in die samelewing neig om 'n deurslaggewende rol te speel.

Om op te som: Suid-Afrikaanse Swart Teologie kan nie losgemaak word van, enersyds, die Amerikaanse Swart Ervaring en die Swart Teologie wat daaruit voortgespruit het nie. Dit kan egter ook nie uitgehaal word uit die breëre bedding van die Bevrydingsteologie wat sy oorsprong in ' $n$ situasie gehad het wat soveel ooreenkomste met die Suid-Afrikaanse swart wêreld toon nie. 


\section{SWART TEOLOGIE EN AFRIKA-TEOLOGIE}

'n Ander verskynsel wat met Swart Teologie in verband gebring moet word, is die sogenaamde Afrika-Teologie.

Die sestigerjare was die dekade van die politieke vrywording van Afrika. Mooi drome is gedroom en groot ideale gekoester. Die onafhanklikheid van die een Afrikastaat na die ander is voorafgegaan deur, en het op sy beurt weer as stimulus gedien vir die opkoms van Afrikanasionalismes, asook die Pan-Afrika-beweging. Afrikanisasie was die wagwoord op alle lewensterreine - ook die teologie.

Die sug was na 'n outentieke teologie en Christendom, 'n kerk en teologie wat tuisgekom het in Afrika, iets waarmee die Afrikaan homself kon identifiseer, sonder om op 'n manier te voel dat hy sy eie verlede en sy siel verloën.

Dit was die soort ideaal wat met die sendingwetenskaplike ideaal van inheemswording nagestreef is. Laasgenoemde begrip was egter baie Westers georiënteer. Die stilswyende veronderstelling was steeds dat dit dieselfde en herkenbare kerk en teologie moes wees wat in inheemse taal, begrippe en gebruike gekleed moes word om sodoende nie meer so duidelik vreemd en ingevoer te lyk nie. Daar is nie altyd rekening gehou met die moontlikheid dat hierdie inheemse teologie en kerk dalk onherkenbaar en onaanvaarbaar vir Westerlinge sou wees nie. Dit is inderdaad wat in baie gevalle gebeur het. Die vroeë toejuiging vir die eerste inisiatiewe op die pad van Afrikanisasie het spoedig verstom.

Die eerste tekens van Swart Teologie in Suid-Afrika (vroeg in 1971) is hoofsaaklik gesien as 'n plaaslike variasie van die embrioniese AfrikaTeologie. Wanneer gepleit word vir swart kerke waar die Swartes hulle eie ding op hulle eie manier kan doen en waar leierskap kan ontwikkel, reageer Die Kerkbode van 14 April 1971 positief:

So 'n opmerking ... dra vir die lidmate van die NG Kerk 'n heel bekende klank. Dit vat ons tradisionele sendingbeleid op besonder treffende wyse saam.

Enkele maande later (Februarie 1972), wanneer hy 'n predikantesaamtrek van die NG Kerk toespreek, stel prof Carel Boshoff (1972: 1) egter 'n teenoorgestelde hipotese:

... as die Swart Teologie in sy volle konsekwensies deur die swartmense van Afrika aanvaar word, (sal) alle moontlikheid tot kommunikasie tussen wit en swart finaal vernietig ... wees. 
'n Maand later verskyn 'n artikel van prof DJ Bosch (1972: 103vv) waarin hy op hierdie verbande ingaan. Hy behandel ses aspekte:

- 'n Nuwe beklemtoning van die waardigheid van die tradisionele kulture in Afrika, in teenstelling met dié van die Weste, kenmerk die huidige periode en lei tot 'n groter aksent op Afrikanisasie (Bosch 1972: 104).

Waar die gesofistikeerde Swartman vroeër geneë was om sy eie kultuur te verag, het hy nou die relatiwiteit van kulture ontdek en die verval van die Westerse kultuur raakgesien. Daarom is daar met nuwe oë na die inheemse kulture gekyk.

- Twee teenstrydige redenasies word gevolg. Aan die een kant word verklaar dat die Afrika-kultuur en sy waardes wesenlik dieselfde is as dié van die 'beskaafde' Weste en daarom volkome aanneemlik is ook vir die progressiewe Swartman. Aan die ander kant word 'n groot diskontinuïteit gehandhaaf en die Westerse kultuur en godsdiens juis as onaanvaarbaar verwerp. Uit hierdie oorde kom die Swart Bewussyn-beweging. Die term 'Nie-Blankes' is volkome onaanvaarbaar - liewer 'Swartes' en 'Nie-Swartes'. 'Black is beautiful.' Veelrassigheid is uit.

- Hierdie selfbewuswording is gevoed deur 'n felle reaksie teen alle vorme van paternalisme. Nie alleen die skeidingsmaatreëls op grond van die voogdyskap-beginsel wat ten grondslag van apartheid lê nie, maar ook die neo-paternalistiese integrasionisme (op Blankes se voorwaardes) van die sogenaamde liberaliste, word verwerp. Daar word nie meer na aanvaarding gesoek nie; die maatstaf is nie langer die sogenaamde Westerse beskaafde norme nie. Blanke meerderwaardigheid is rassisme en moet teengegaan word. Die alternatief is nie altyd duidelik nie, maar dit is 'n groot nee vir voorsêery, dit is 'n botweg weiering om maar net op sleeptou geneem te word op watter (goeie) weg ook al. Daarom word met die voete gestem: Boikotte is aan die orde van die dag.

- Uiteraard ontwikkel hier 'n spanning tussen partikularisme - om die eie ding op eie wyse te doen en te beheer - en universalisme - kontak en kommunikasie met die buitewêreld. Die rug kan nie maar sommer op die historiese prosesse gedraai word nie. Die weerstande en boikotte is nie altyd logies houdbaar nie. Daarby is verskeie aspekte van die Westerse kultuur aantreklik en begeerlik. Daar word egter nie gepoog om hierdie spanning in 'n netjiese formule op te los nie.

- Afrikanisasie en die Swart Teologie is ook 'n reaksie op die tradisionele piëtistiese teologie van die sending in Afrika. Uit reaksie teen 
die vertikale oorbeklemtoning kom daar nou 'n horisontalistiese trek na vore. Afrika se sondebegrip het in ieder geval steeds hoofsaaklik beperk gebly tot die wanverhoudings tussen mense (dood of lewend). Die sosiale aspekte van vervreemding is nou beklemtoon. Hier het die Bevrydingsteologie en die Amerikaanse Swart Teologie die vonk laat oorspring. Die uitgangspunt het geword die onvrye, onderdrukte en uitgebuite Swartmens en sy geestelike, ekonomiese en sosio-politieke bevryding. Hierdie beklemtoning word dominant, maar is nie die enigste nie. Natuurlik is daar altyd oorreaksies, maar om die beweging bloot daartoe te reduseer, is ' $n$ onregverdige verenging.

- Op prakties kerklike terrein was die minste effek van Afrikanisasie in ieder geval ' $n$ nuwe openheid om tradisionele elemente in die erediens en kerklike praktyk in te voer. Dit wat deur die program van inheemswording met min welslae probeer is, het nou vanself mode geword. Maar nie net in die liturgie nie, maar ook in die teologie, is daar groot aktiwiteit: Die Afrika-Teologie kom op dreef.

Daar word warm debatte gevoer oor die onderskeid al dan nie tussen Swart Teologie en Afrika-Teologie. In kort en miskien oorvereenvoudig kan gesê word dat, soos die name aandui, die Afrika-Teologie die mens van Afrika op die oog het: sy kulturele agtergrond en basiese waardes, lewens- en wêreldbeskouing. Die Afrika-Teologie moet tot 'n vergelyk kom met die tradisionele Afrika-godsdienste en magiese gedagtes. Vir die Swart Teologie is die konteks dié van die ontmenslikte Swartman, veral in die neo-koloniale situasie. ' $n$ Nuwe menswaardigheid en bevryding word gesoek. Nie die kulturele, maar die sosio-politieke situasie van die dag is die konteks.

As hierdie soort onderskeiding die volle waarheid was, sou dit nie nodig gewees het vir die debat om voort te duur nie. Tog word daar hewige argumente oor ' $n$ wye spektrum van opinies gevoer deur Swartmense self.

\section{SKAKERINGE IN DIE SWART TEOLOGIE}

Miskien kan ons teruggaan na 'n vroeë onderskeiding van Bosch van vyf strome in die Swart Teologie (1974: 6vv). Alhoewel dit die situasie van meer as 'n dekade gelede reflekteer, is dit dalk interessant om te sien of en in hoeverre hierdie onderskeie strominge sterker of swakker geword het. Dan sal die Kairos Dokument dalk beter geplaas kan word. 
Volgens Bosch is die eerste stroom dié wat eintlik 'n voortsetting van die Amerikaanse model is. Dit was die stroom wat in sy radikaliteit ongetwyfeld die meeste publisiteit geniet het. Vermoedelik is dit ook die beeld wat die Swart Teologie by die gemiddelde geïnteresseerde Suid-Afrikaner dra. Alhoewel ook hier 'n wye spektrum van denke teenwoordig is, kan gesê word dat die mees bekende teoloë en kerkleiers, soos artsbiskop Desmond Tutu, dr Alan Boesak en dr Manas Buthelezi, min of meer in hierdie stroom beweeg. Hierdie groep handhaaf min of meer die onderskeiding hierbo gemaak tussen Swart en Afrika-Teologie: Laasgenoemde het te doen met Afrikanisasie; eersgenoemde met bevryding - ook van die verslawende elemente van die kulturele erfenis.

Die tweede stroom verskil in dié sin dat hulle ' $n$ nouer verband tussen die twee sien. Die probleem is die 'Zombi-Christendom' van die Afrikaan wat deur die Westerse teologie en kerklike lewe versmoor is (Setiloane) (Bosch 1973: 8). Hierdie mense probeer loskom van die kultuur- en filosofiese oorheersing en wil kom tot 'n Bybelse teologie wat spreek tot die siel van die Afrikaan. Vir hierdie pogings is daar natuurlik veel meer waardering van die kant van wit teoloë, en dit is ook die soort pogings wat van vroeg af deur die All Africa Council of Churches (AACC) gepropageer is. Nie dat die guns van Westerse teoloë verwelkom word nie.

'n Derde stroom is volgens Bosch (1973: 9) ook te onderskei: dié wat 'n noue verband tussen Swart Teologie en die tradisionele godsdienste van Afrika sien. Sommige praat van die godsdienste van Afrika as die praeparatio evangelica, 'n soort Ou Testament vir Afrika. Ander verwerp die Christendom as sodanig omdat dit nie alleen niks nuuts gebring het nie, maar selfs skade gedoen het.

Die vierde stroom wys daarop dat die mees outentieke vorm van Swart Teologie al vir baie jare bestaan in die beweging van die so genoemde Onafhanklike Swart Kerke. Daar is die saak van bevryding steeds sentraal (Bosch 1973: 11), hoewel dit dan nie soseer in die politieke sin van die woord is nie. Hierdie Swart Teologie is ook nie geskrewe en uitgewerk nie, maar funksioneer in die rituele en geloofsbelewenis van miljoene Suid-Afrikaanse swart Christene. GC Oosthuizen (1978: 70v) gooi die saak ook oor hierdie boeg wanneer hy skryf oor die uitdaging van die Swart Teologie tot die blanke kerke van Suid-Afrika. Terwyl daar sekerlik 'n saak hiervoor uitgemaak kan word, moet dit nogtans betwyfel word of die leiers van die Onafhanklike Swart Kerke hulle benadering as 'Swart Teologie' sou beskryf, behalwe as hulle 'n 
opportunistiese punt sou wou maak. Die feit is dat die term in 'n sekere sin terminus technicus geword het vir die soort teologie van die eerste stroom, of miskien dan ook die volgende, die vyfde stroom van Bosch.

Die vyfde stroom is ' $n$ kombinasie of ' $n$ saamvloei van die eerste twee. Van die begin af was daar' $n$ wedersydse beïnvloeding en het die debat eintlik langs hierdie linie geloop. Die mees permanente en vrugbare stroom sou goedskiks dié wees wat die brug tussen Afrika en Amerika slaan. Dit is so dat die Amerikaanse Swart Teologie niks van Afrika gehad het nie. Gefilter deur die Afrika-bewussyn kry dit mettertyd 'n ander stempel. Interessant is ook die werk van Swart Gereformeerde teoloë soos Boesak, Mofokeng, Ntoane en andere wat 'n al groter akademiese erkenning vir 'n aangepaste Swart Teologie verwerf.

'n Paar kenmerke van al die vorme van Swart Teologie is eerstens sy oproep tot die Swartmense om bevry te raak uit 'n kneg-mentaliteit. Tweedens is daar 'n verwerping van Blankes se tokenism (verligtheid, vriendelikheid, neerbuigendheid) omdat dit die eintlike sake vermy. Derdens is dit onbeskaamd situasie-teologie. Dit stel nie daarin belang om begryp of aanvaar te word deur mense wat nie die situasie deel nie. Dit is anti-denominasioneel en ekumenies, maar tog sektaries omdat dit nie probeer om algemeen geldig te wees nie. Die situasie (soos die Swart Teoloog dit ervaar) is die uitgangspunt en die hermeneutiese sleutel. (Daarom sê Sundermeier dat dit minder teologie is as hermeneutiek.) Lukas 4: $18-19$ is vir die Swart Teologie wat Romeine 1: 17 vir die Hervorming geword het. Swart Teologie is ook anti-piëtisties en selfs anti-evangelies (in die enger sin van die woord). Die evangeliese stroom van die kerk kan moeilik daarmee vrede maak.

Maar ten spyte van al die afwysings en skerp kritiek is die woordvoerders ook eksplisiet besig met blanke Christene. Ook húlle bevryding uit die bande van die verlede word gesoek. Swart Teologie probeer ook daartoe 'n bydrae lewer.

\section{DIE KAIROS DOKUMENT}

Is die aanbevole Profetiese Teologie van die Kairos Dokument Swart Teologie? Of is dié nuwe term 'n vervanging van Swart Teologie? Is dit enigsins belangrik om dié vrae te vra?

Ek gaan tog probeer aantoon dat die Kairos Dokument gesien moet word as die jongste vorm en uitvloeisel van die Swart Teologie - met al die winspunte en kritiek wat daarmee gepaard gaan. Of die term Profe- 
tiese Teologie mettertyd as benaming gaan oorneem, weet ek nie en dit sal nog gesien moet word. Dat dit 'n meer aanvaarbare terminologie is wat ' $n$ beter kans staan om ook politieke revolusies te oorleef, is seker waar. Interessant is die begrip 'kontekstualiteit' in die benaming van die instansie wat die Kairos-teoloë verteenwoordig en wat miskien die kern van hulle teologiese oortuiging uitmaak: Institute for Contextual Theology. Wat verder waar is, is dat die dokument, veral in sy konsephersiening (wat ek eers einde Augustus 1986 te siene gekry het), minder 'Swart-Teologies' is as die aanvanklike teologiese uitinge. Trouens, dit wil my voorkom asof die tweede uitgawe van die Kairos Dokument betekenisvolle aanpassings in die rigting van versigtiger formulerings gemaak het, 'n gemis wat waarskynlik talle mense weerhou het van 'n aanvanklike onderskrywing van die dokument. Op die oomblik stel die welslae van die Kairos Dokument binne- en buitelands egter beslis die Swart Teologie in die skadu.

Wanneer die Kairos Dokument as Swart Teologie geklassifiseer word, moet natuurlik goed verstaan word dat nie al die skakeringe van die Swart Teologie, soos hierbo uiteengesit, daarin gereflekteer word nie. Of is hierdie teologie ver genoeg verwyder van die vroeëre Swart Teologie dat dit liewer Bevrydingsteologie genoem moet word?

Die dokument het sy fisiese ontstaan gehad in die swart woonbuurte aan die Rand, maar het meer nog die swart kerk en die township experience as sy basis. Die opstellers vertel self dat hulle (vermoedelik hoofsaaklik Swartmense) begin teologiseer het oor dié situasie. Mens kan nie die gevoel ontkom nie dat die blanke ondertekenaars van die aanvanklike dokument dit eintlik uit simpatie (mee-gevoel) met die opstellers gedoen het, maar dat dit nie regtig húlle dokument was nie. Dit lyk voorts asof baie van die byvoegings en herformulerings in die tweede uitgawe 'n tegemoetkoming van hierdie mense is.

Die styl van die dokument toon dieselfde ongeërgdheid ten opsigte van balans wat kenmerkend van die Swart Teologie is. ' $n$ Punt wil egter gemaak word: 'n diepgesetelde gevoel moet tot uiting kom; 'n roep om hulp, ' $n$ traan word gestort - dis emosionele teologie hierdie. En hulle verwag dat niemand hulle daarvoor kan verkwalik nie. Dit is egter wanneer dit as ernstige teologie aangebied word dat die vraagtekens vermeerder en dat gevra word vir meer presiese formulerings en minder wilde uitsprake. Klaarblyklik is baie van hierdie hindernisse in die hersiening uit die weg geruim en kan makliker tot die eintlike teologiese sake deurgedring word.

Die Kairos Dokument se teologie is dié van die Bevrydingsteologie - 
en die Suid-Afrikaanse Swart Teologie. Reeds die woord kairós en die opneem daarvan as 'n teologiese konsep is aan die Bevrydingsteologie ontleen. Die tekens van die tye moet raakgesien word en die uur van beslissing het aangebreek. Kairós is die oomblik van krisis, ' $n$ geleentheid om die regte besluite te neem, maar ook die verkeerdes.

Die Kairos Dokument se hermeneutiek is ook dié van Bevrydingsteologie. Die situasie van die massa word as dié hermeneutiese sleutel gebruik. Dit is al lankal erken dat vir 'n regte verstaan van die Skrifboodskap daar 'n gedurige heen-en-weer-beweging tussen teks en konteks moet wees, maar dit lyk tog asof in hierdie teologie die bepaalde konteks (soos deur sommige beleef) oorheersend word.

Hier word dieselfde eise gestel van solidariteit met die armes. Alleen dié kerk is ware kerk wat ondubbelsinnig hom skaar aan die kant van die onderdruktes en teen die tirannie van die regering, die ongeloofwaardigheid van die Wit Kerk en almal wat baat uit die status quo. Konfrontasie is nodig om die reg te laat seëvier. Op 'n skerp en onmisverstaanbare wyse word die status quo-teologie (deur hulle 'Staatsteologie' genoem) veroordeel. Net so verfoeilik is die 'Kerkteologie' wat mooi evangeliese woorde gebruik, maar ook glad nie in ' $n$ werklike radikale verandering van die samelewing belangstel nie. Alleen ' $n$ radikale 'Profetiese Teologie' wat konsekwent dic ander teëgaan, kan as hoop vir die mense voorgehou word.

Die teenstanders word nie gespaar nie. (Na my gevoel toon die hersiening veel meer begrip vir die goedgelowige en goedwillige mense wat vasgevang is in die stelsels wat hulle beveg.) Hulle word van afgodery beskuldig, godslastering en die hoogste vorm van kettery. Die onderdrukkers kan en hoef nie vergewe te word voordat hulle nie eers grondige berou en bekering getoon het nie. Hulle glo in bitter medisyne, of so nie chirurgie.

Alles berus natuurlik op die nou-reeds-bekende analise van die samelewing as bestaande uit onderdrukkers en onderdruktes. Die pynlike feit is dat daar Christene (oftewel mense wat sê hulle is Christene) aan beide kante van die konflik is. Dit kan alleen die gevolg wees van ongehoorsaamheid aan die God van bevryding. Dit is sonde om hier te praat van versoening en vrede - asof dit moontlik en gewens is om versoening tussen goed en kwaad te bewerk. Hierdie Marxistiese analise van die samelewing maak die Kairos Dokument nog glad nie 'n kommunistiese dokument nie, maar hierdie bril om na die situasie te kyk, kleur wel die hele saak. Ook die styl is dié van konflik (klassestryd) en die woordeskat revolusionêr. Soos wat in Latyns-Amerika gebeur het, 
gee die Kairos Dokument hier te lande 'n teologiese onderbou aan 'n ideologie, en roep gelowiges op om deel te word van ' $n$ stryd wat daarop gemik is om ' $n$ heersende ideologie te beveg en te vernietig.

\section{SLOT}

Wat sal ons van dit alles sê? Het die doemprofete dit reg gehad en is alle kontak tussen swart en wit teoloë afgebreek? Of het ons hier met iets te doen wat die toets van die tyd deurstaan het en die weg van die toekoms aandui?

Ek dink albei uiterste standpunte is oordrewe. Die Kairos Dokument, ten spyte van sy ongeduld en skynbaar onchristelike onvergewensgesindheid by tye, het ' $n$ dringende uitnodiging tot gesprek gerig. Die eerste hersiening toon al klaar ' $n$ bereidheid tot aanpassing. Aan die ander kant het Wit Teologie - volgens alle aanduidings die eintlike aanleidende oorsaak vir Swart Teologie - alreeds baie selfondersoek gedoen. Baie min teoloë, indien enige, staan nog by die ou soort denke wat teologiese begronding aan die ideologie van apartheid gegee het.

Wat van die uiterste belang is, is dat Swart Teologie en sy uitvloeisel, die Kairos Dokument, gesien moet word as dit waarvoor hulle hulleself aanbied: ' $n$ uitdaging tot die kerk. Wedersydse en ernstige selfondersoek en eerlike kommunikasie is nodig. Die huidige impasse moet deurbreek word!

\section{Literatuurverwysings}

BAM, G 1985. Kerk van die armes - ' $n$ weg vir die NG Sendingkerk in SA? Die Ligdraer, 16 Maart - 1 Junie 1985 (5 aflewerings).

BOFF, CM 1985. Theologie der Befreiung. Eine Einführung in ihre Grundlagen. Zeitschrift für Missionswissenschaft und Religionswissenschaft 69/3, 161-178.

BOSCH, DJ 1972. Inheemswording, Afrikanisasie en Swart Teologie. NGTT 13/2, $103-115$.

BOSCH, DJ 1974. Currents and crosscurrents in South African Black Theology. Journal of Religion in Africa 6/1, 1-22.

BOSHOFF, CWH et al 1972. Swart Teologie? Pretoria: NGKB.

BOSHOFF, CWH 1980. Swart Teologie van Amerika tot in Suid-Afrika. Pretoria: NGKB.

DEIST, FE 1977. The liberation motif in the Old Testament and the theology of liberation. Missionalia 5/2, 58-69.

ESCOBAR, $S$ et al 1983. A Latin American critique of Latin American Theology. Evangelical Review of Theology 7/1, 48-62.

HÄSELBARTH, H 1977. Die Relevanz der Schwarzen Theologie für das freie Afrika.

Zeitschrift für Mission 3/2, 69-83.

ISWEN KOMMUNIKASIE 1986. Spesiale Kairos-uitgawe, Junie 1986, 8/1

LE ROY, WR 1979. Liberation Theology. The Reformation Review 24/4, 193-214. 
NEELY, A 1978. Liberation Theology in Latin America: Antecedents and autochthony. Missiology 6/3, 343-370.

OOSTHUIZEN, GC 1978. Die Herausforderung der Schwarzen Theologie für die weissen Kirchen Südafrikas. Zeitschrift für Mission 4/2, 70-82.

ROBERTS, JD 1971. Introduction, in Quest for a Black Theology. Philadelphia: Pilgrim Press.

VAN WYK, JA 1977. Latin American Protestant theology of liberation. Missionalia 5/2, 86-91.

VATICAN, ROME 1986. Instruction on certain aspects of the theology of liberation. Evangelical Review of Theology 10/2 (Apr 1986), 115-128; 10/3 (Jul 1986), 228-238. 